Jurnal Pustaka Budaya. Vol. 5, No. 1, Januari 2018

Copyright @2018, pISSN: 2355-1186 / eISSN: 2442-7799

Available Online at: https://journal.unilak.ac.id/index.php/pb

\title{
PEKERJAAN PUSTAKAWAN DI BAGIAN LAYANAN TEKNIS PADA ERA TEKNOLOGI DIGITAL :
}

(Sebuah kajian fenomenologi tentang pengalaman pustakawan di bagian layanan teknis Di Dinas Perpustakaan Dan Arsip Daerah (DIPUSIPDA) Provinsi Jawa Barat) Niar Surry Nafizah ${ }^{*}$ dan Yunus Winoto ${ }^{* *}$

Universitas Padjadjaran Bandung, Indonesia yunus.winoto@unpad.ac.id

Naskah diterima: 11 Desember ; direvisi: 18 Desember; disetujui: 25 Desember

\begin{abstract}
Abstrak
Penelitian ini bertujuan untuk mengetahui pengalaman pustakawan dispusipda dalam kegiatan-kegiatan layanan teknis pada era teknologi digital. lokasi penelitian ini dilakukan di perpustakaan dispusipda provinsi jawa barat. fokus penelitian ini meliputi 3 (tiga) aspek yakni pengalaman pustakawan dalam kegiatan inventarisasi di perpustakaan dispusipda, pengalaman pustakawan dalam kegiatan klasifikasi di perpustakaan dispusipda, dan pengalaman pustakawan dalam kegiatan katalogisasi di perpustakaan dispusipda. metode penelitian yang digunakan adalah metode kualitatif dengan pendekatan fenomenologi. untuk teknik pengumpulan datanya dilakukan melalui wawancara, dan observasi. Berdasarkan hasil penelitian diketahui bahwa penggunaan teknologi informasi dalam kegiatan layanan teknis di Dinas Perpustakaan dan Arsip Daerah Provinsi Jawa Barat belum berjalan dengan baik. Hal ini terlihat dari pengalaman pustakawan di bagian penyeleksian dan pengadaan bahan pustaka yang masih mengerjakan tugasnya secara manual. Begitu juga di bagian pengolahan seperti bagian inventarisasi masih dilakukan secara manual dengan menggunakan buku induk, pengklasifikasi masih menggunakan buku DDC manual dan belum menggunakan DDC elektronik apalagi mengguakan DDC on-line. Sedangkan untuk kegiatan pengkatalogan sudah menggunakan software pengolahan data perpustakaan namun belum terintegrasi.
\end{abstract}

Kata kunci: layanan teknis, teknologi informasi, pengalaman, pustakawan, perpustakaan umum.

\begin{abstract}
This study aims to determine the experience of librarians dispusipda in technical service activities in the era of digital technology. The location of this research is done in library dispusipda west java province. The focus of this research includes 3 (three) aspects of librarian experience in inventory activities in library dispusipda, librarian experience in classification activities in library dispusipda, and librarian's experience in cataloging activities in library dispusipda. Research method used is qualitative method with phenomenology approach. For its data collection techniques is done through interviews, and observation. Based on the results of research known that the use of information technology in technical service activities in the Office of Library and Regional Archives of West Java province has not run well. This is evident from the experience of librarians in the selection and procurement of library materials that are still doing their work manually. Similarly in the processing part such as the inventory section is still done manually by using the parent book, the classifier is still using the manual DDC book and have not used the electronic DDC let alone using DDC on-line. While for pengkatalogan activities already using data processing software library but not yet integrated.
\end{abstract}


Keywords: technical services, information technology, experience, librarians, public libraries.

\section{Pendahuluan}

$\begin{array}{lrr}\text { Dewasa } & \text { kini } & \text { manusia } \\ \text { memerlukan informasi } & \text { dalam } \\ \text { melakukan setiap kegiatannya, oleh } \\ \text { karena itu banyak sekali temapat } \\ \text { penyedia informasi dan aksesnya pun } \\ \text { sangat mudah sehingga masyarakat } \\ \text { sangat terbantu dalam memenuhi } \\ \text { kebutuhan informasinya. Tak } \\ \text { terkecuali dengan perpustakaan, } \\ \text { perpustakaan sebagai lembaga } \\ \text { penyedia }\end{array}$ dimanfaatkan oleh masyarakat untuk memenuhi kebutuhan informasinya. Perpustakaan menjadi sarana yang dipilih oleh masyarakat dalam memenuhi kebutuhan informasi, karena dengan pengetahuan masyarakat umum bahwa perpustakaan merupakan tempat dengan banyak sekali koleksi bukubuku di dalamnya sehingga dapat di manfaatkan oleh masyarakat. Menurut Sulistyo - Basuki (1991, 3) "Perpustakaan ialah sebuah ruangan, bagian sebuah gedung. ataupun gedung itu sendiri yang digunakan untuk menyimpan buku dan terbitan lainnya yang biasanya disimpan menurut tata susunan tertentu untuk digunakan pembaca, bukan untuk dijual." Perpustakaan berperan penting dalam menunjang kebutuhan informasi masyarakat, maka dari itu eksistensi perpustakaan harus selalu terjaga, terpelihara serta dikembangkan. Untuk mendapatkan semua itu tentunya harus dengan pengelolaan yang baik, serta diperlukan dukungan dari masyrakat itu sendiri.

Perpustakaan sebagai penyedia informasi tentu di dalamnya terdapat koleksi-koleksi bahan pustaka untuk dapat menunjang kebutuhan informasi masyarakat. Koleksi di perpustakaan sudah pasti jumlahnya banyak serta berbagai macam judul dengan kualitas yang baik untuk memenuhi kebutuhan informasi penggunanya. Koleksi-koleksi yang tersedia di perpustakaan tentu harus dengan pengawasan yang tepat. Oleh karena itu di butuhkan pengelolaan yang sangat baik agar koleksi bahan pustaka dapat tertangani dengan tepat.

Pengelolaan koleksi bahan pustaka harus di tangani oleh orangorang yang berkompeten di bidangnya. Orang yang tepat adalah pustakawan karena pustakawan yang memiliki latar belakang pendidikan di bidang perpustakaan. Menurut Poerwadarminta dalam Aziz (2006, 44) mengatakan bahwa, "Pustakawan adalah ahli perpustakaan. Dengan pengertian tersebut berarti pustakawan sebagai tenaga yang berkompeten dibidang perpustakaan, dokumentasi, dan informasi".

Pustakawan yang mengelola bahan pustaka di perpustakaan adalah yang menangani layanan teknis perpustakaan. Dimana di dalamnya mengelola koleksi bahan pustaka dari mulai pengadaan, pengkatalogan, pengklasifikasian dan tahapan lain sampai koleksi bahan pustaka dapat di layankan kepada pemustaka.

“... pelayanan teknis, yang mencakup kegiatan pengadaan, pengatalogan dan perawatan koleksi. Prosedur dan mekanisme kerja dari kegiatan tersebut harus dirumuskan dengan baik agar pekerjaan pembinaan koleksi dapat berjalan dengan lancar. Standar-standar pengolahan harus ditetapkan, dan peralatan-peralatan serta bahanbahan yang diperlukan untuk itu harus disediakan." Ridwan Siregar (2004, 152)

Kegiatan layanan teknis penting dilakukan agar memudahkan dalam managemen koleksi bahan pustaka, dengan begitu memberikan kemudahan bagi pengguna dalam proses pencarian informasi yang di butuhkan. Jadi setiap perpustakaan wajib melakukan kegaitan layanan teknis karena bahan pustaka yang masuk ke perpustakaan harus di olah agar dapat di layankan kepada pengguna. Selain itu kegaitan layanan tekni berguna untuk mengontrol 
setiap bahan pustaka yang masuk dan yang di layankan kepada pengguna. Dan jika tanpa kegiatan layanan tkenis di perpustakaan maka layanan di perpustakaan tidak akan berjalan dengan baik, maka dari itu kegaiatan layanan teknis di perpustakaan sangat penting di lakukan.

Kegiatan layanan teknis di Dinas Perpustakaan dan Arsip Daerah (DISPUSIPDA) Provinsi Jawa Barat melalui beberapa tahap umum yakni kegiatan pengadaan koleksi, lalu di klasifikasi dan katalogisasi, kemudian entri data ke dalam sebuah sistem LMS (Library Managemen System), di kategorikan kemudian dilayankan kepada pengguna. Namun dengan seiring perkembangan zaman, di era teknologi digital seperti sekarang ini kegiatan layanan teknis dilakukan dengan bantuan sistem teknologi canggih demi memudahkan pustakawan pada saat kegiatan layanan teknis. Keberadaan teknologi yang semakin maju perkembangannya di negeri ini tentu sangat membentu pustakawan dalam kegiatan layanan teknis tersebut. Dengan adanya perangkat komputer serta software yang dapat membantu proses pengolahan bahan pustaka tersebut. Hal ini terjadi mengingat, koleksi bahan pustaka yang ada di perpustakaan jumlahnya sangat banyak sehingga tidak memungkinkan jika kegiatan pengolahan dilakukan secara manual, pustakawan akan kesulitan dan tentu akan memakan waktu yang cukup lama, sehingga pelayanan akan kurang optimal.

Untuk kegiatan layanan teknis di perpustakaan DISPUSIPDA Provinsi Jawa Barat di tangani oleh pustakawan-pustakawan yang berpengalaman. Di bagian layanan teknis khusus yang menangani adalah pustakawan, dengan berbagai latar belakang pendidikan. Namun semua sudah memiliki sertifikat resmi sebagai pustakawan yang tentunya di peroleh melalui proses yang tidak mudah dan dengan syarat-syarat yang sesuai dengan aturan sebagai pustakawan.
Dengan bekal ilmu yang cukup dari mengikuti berbagai macam pelatihan dan kemampuan yang dimiliki, pustakawan dapat melakukan kegiatan layanan teknis di perpustakaan DISPUSIPDA Provinsi Jawa Barat. Di era teknologi digital seperti sekarang ini juga pustakawan dapat terbantu dengan bantuan teknologi yang ada. Khususnya di perpustakaan DISPUSIPDA Provinsi Jawa Barat yang sebagian besar kegiatannya dibantu oleh teknologi, mulai dari pelayanan teknis dan non teknis. Dengan begitu secara otomatis pustakawan di perpustakaan DISPUSIPDA Provinsi Jawa Barat sudah menguasai teknologi yang ada. Namun, dibalik semua manfaat itu tidak semua kegiatan berjalan dengan mulus. Kadang kala ada juga hambatan yang menghampiri para pustakawan, namun semua hambatan dapat teratasi dengan baik karena mereka telah berpengalaman.

Peneliti tertarik untuk mengidentifikasi pengalaman yang dialami oleh pustakawan DISPUSIPDA Provinsi Jawa Barat dalam melakukan kegiatan layanan teknis. Pengalaman pustakawan pada saat melakukakan kegiatan layanan teknis karena pengalaman merupakan sesuatu yang di alami setiap orang dan pengalaman yang dirasakan itu tentunya berbedabeda, begitupun dengan pustakawan mereka memiliki pengalaman yang berbeda-beda pada saat melakukan kegiatannya terutama pada saat melakukan kegiatan teknis di perpustakaan. Penelitian ini adalah untuk mengetahui pengalaman atas dasar perspektif pustakawan DISPUSIPDA Provinsi Jawa Barat itu sendiri. Menurut penulis topik tentang pengalaman pustakawan DISPUSIPDA Provinsi Jawa Barat dalam kegiatankegiatan layanan teknis ini adalah hal yang penting karena dengan pengalaman yang dialami oleh pustakawan pada saat melakukan kegiatan layanan teknis berpengarauh pada layanan non teknis untuk kebutuhan informasi para pengunjung atau pemustaka DISPUSIPDA Provinsi Jawa Barat itu sendiri. 


\section{Metode Penelitian}

\subsection{Metode Penelitian}

Metode yang digunakan dalam penelitian ini adalah metode kualitatif dengan pendekatan fenomenologi. Littlejohn dalam Kuswarno (2009) mendefinisikan fenomenologi sebagai studi tentang pengalaman yang datang dari kesadaran atau cara kita memahami sesuatu dengan secara sadar mengalami sesuatu tersebut. Sedangkan menurut Hegel dalam Kuswarno (2009) fenomenologi mengacu pada pengalaman sebagaimana yang muncul pada kesadaran, lebih lanjut ia menjelaskan fenomenologi adalah ilmu menggambarkan apa yang seseorang terima, rasakan dan ketahui di dalam kesadaran langsungnya dan pengalamannya. Dan apa yang muncul dari kesadaran itulah yang disebut sebagai fenomena.

Prinsip fenomenologi
berkenaan dengan pemahaman
tentang bagaimana keseharian, dunia
intersubyektif (dunia kehidupan) atau
juga disebut Lebenswelt terbentuk.
Fenomenologi bertujuan mengetahui
bagaimana kita menginter-pretasikan
tindakan sosial kita dan orang lain
sebagai sebuah yang bermakna
(dimaknai) dan untuk merekonstruksi
kembali turunan makna (makna yang
digunakan saat berikutnya) dari
tindakan yang bermakna pada
komunikasi intersubjektif individu
dalam dunia kehidupan sosial.

Jadi fenomenologi dalam penelitian adalah untuk memahami pengalaman pustakawan DISPUSIPDA Provinsi Jawa Barat dalam melakukan kegiatan-kegiatan layanan teknis dari sudut pandangnya langsung dan menurut prespektif pustakawan itu sendiri kaitannya dengan teknologi. Karena setiap sudut pandang dan perspektif yang dirasakan oleh masing-masing pustakawan akan berbeda-beda.

\subsection{Sumber Data}

Sumber data dalam penelitian terdiri data primer yang diperoleh dari hasil observasi dan wawancara dengan para pustakawan Bapusipda Provinsi Jawa Barat dan observasi dengan para pustakawan di bagian layanan teknis serta data sekunder yang diperoleh dari data statistik perpustakaan DISPUSIPDA Provinsi Jawa Barat serta dokumen-dokumen lainnya yang relevan dengan kegiatan penelitian.

\subsection{Teknik Pengumpulan Data}

Pertama wawancara dilakukan dengan cara meminta informan untuk mengungkapkan pengalaman mereka dalam melakukan kegiatan-kegiatan layanan teknis di perpustakaan DISPUSIPDA Provinsi Jawa Barat dalam bentuk rangkaian kejadian. Adapun informan dalam penelitian ini adalah pustakawan bagian layanan teknis di perpustakaan.

Kedua observasi, Peneliti mengamati langsung situasi dan kondisi di lapangan untuk memperoleh informasi mengenai gambaran kegiatan layanan teknis yang dilakukan oleh pustakawan di perpustakaan DISPUSIPDA Provinsi Jawa Barat. Dengan begitu peneliti dapat melihat, mencatat perilaku dan kejadian sesuai dengan yang terjadi di lapangan.

Selanjutnya studi Kepustakaan, dilakukan untuk mengumpulkan data sekunder dalam mendukung analisis hasil penelitian yang akan dilakukan.

\section{Hasil Penelitian dan Pembahasan \\ 3.1 Hasil Penelitian}

Sebagaimana yang telah dipaparkan di atas, penelitian ini menjelaskan tentang pengalaman pustakawan yang berkerja di bagian layanan teknis pada era teknologi digital. Adapun mengenai pengertian layanan teknis jika merujuk pada pendapat Mary L Kao (2001, 3) pengertian layanan teknis adalah suatu layanan perpustakaan yang sifatnya di belakang layar. Kegiatan ini meliputi kegiatan pemilihan dan pengadaan bahan pustaka serta kegatan pengolahan bahan pustaka yang meliputi inventarisasi, pengklasifikasi dan pengkatalogan 
serta bahan pustaka dan klasifikasi dan katalogisasi.

Salah satu wujud perkembangan ilmu pengetahuan dan teknologi adalah perkembangan teknologi ke arah digital. Dengan masuknya era teknologi digital kita tidak bisa lepas dari perangkat teknologi yang serba elektronik dan teknologi menjadi alat yang membantu kebutuhan manusia. Hadirnya era digital telah membawa berbagai dampak dalam kehidupan dan aktivitas manusia. Salah satu dampak positif masuknya era digital ini adalah adanya efiensi dalam pekerjaan. Hal ini terlihat dalam penyelenggaraan perpustakaan di beberapa negara maju, dimana kegiatan pemilihan dan pengadaan bahan pustaka maupun kegiatan pengolahan bahan pustaka dapat dijalankan secara efektif dan efisien.

Berbicara lebih jauh tentang era digital, sebenarnya Indonesia mengalami keterlam-batan hampir satu dawarsa dalam mengadopsi era digital ini. Selain itu juga mengenai perkembangan teknologi informasi ini jika dikaitkan dengan penyelenggaraan perpustakaan, kita telah masuk era yang disebut library 3.0. Adapun sebagaimana diketahui sejarah perkembangan web menurut Maesaroh dalam Yunus Winoto (2017) telah mengalami perubahan yakni diawali dengan munculnya web 1.0 yang dimulai tahun 1989-2005 dimana pada web 1.0 ini para penggunanya hanya berperan sebagai pembaca atau penonton saja, selanjutnya muncul web 2.0 dan munculnya istilah library 2.0 . Dengan adanya library 2.0 ini perpustakaan tidak hanya mampu membangun perangkat lunak atau software khusus milik perpustakaan namun bisa juga memanfaatkan berbgai media sosial lainnya sebut saja whastapp, facebook, youtube, line, instagram, dll. Salah satu keuntungan dengan diterapkannya library 2.0 ini para pemustaka melakukan peminjaman antar perpustakan serta melakukan document delivery. Berkaitan dengan hal ini staf perpustakaan dapat dengan segera menginformasikan pada pemustaka jika ada permintaan informasi yang dibutuhkan pemustaka.

Ada beberapa perbedaaan dan kelebihan yang signifikan dari web 3.0 atau di perpustakaan dikenal dengan istilah library 3.0 dengan generasi sebelumnya diantaranya adalah pengguna perpustakaan dapat membaca, menulis dan juga sambil menjalankan website perpustakaan. Selain itu juga dalam library 3.0 dikenal istilah "one gate for all" artinya hanya dengan mengetik satu kata kunci kita bisa menampilkan hasil penelusuran dari berbagai data yang terkoneksi dari semua pangkalan data.

Hadirnya teknologi dalam kehidupan manusia termasuk dalam kegiatan penyelenggaraan perpustakaan adalah sebuah keniscayaan yang tidak bisa dihindari. Berkaitan dengan hal ini untuk tetap bisa mengimbangi perkembangan ilmu pengetahuan dan teknologi informasi serta semakin tingginya ekspektasi atau harapan para pemustaka terhadap kualitas layanan perpustakaan, maka dituntut tenaga pengelola perpustakaan (pustakawan) yang memiliki kompetensi dalam artian memiliki pengetahuan dan pemahaman dan keterampilan di bidang perpustakaan serta memiliki penguasaan dalam bidang teknologi informasi. Oleh karena demikian, dalam penelitian ini penulis akan memaparkan bagaimana pengalaman para pustakawan Dinas Perpustakaan dan Arsip Daerah Provinsi Jawa Barat dalam melakukan pekerjaaanpekerjaaan teknis di bidang perpustakaan kaitannya dengan memasuki era teknologi digital.

Untuk membahas hasil penelitian tentang kegiatan teknis yang dilakukan pustakawan perpustakaan DISPUSIPDA Provinsi Jawa Barat, peneliti membagi dua kegiatan teknis yang dilakukan pustakawan yakni kegiatan pemilihan dan pengadaan bahan pustaka serta kegiatan pengolahan bahan pustaka 
yang meliputi inventarisasi bahan pustaka, klasifikasi dan katalogisasi. Adapun dari hasil penelitian yang telah kami lakukan dapat dikemukakan pengalaman pustakawan sebagai berikut :

\subsubsection{Pengalaman Pustakawan DISPUSIPDA Provinsi Jawa Barat Dalam Melakukan Penyeleksian dan Pengadaan Bahan Pustaka.}

Salah satu tahapan dalam kegiatan layanan teknis perpustakaan adalah kegiatan penyeleksian dan pengadaan bahan pustaka. Pengertian penyeleksian bahan pustaka secara sederhana dapat diartikan sebagai sebuah proses memilih bahan pustaka untuk menjadi koleksi perpustakaan. Dalam melakukan penyeleksian ini terkait dengan berbagai hal seperti prinsip-prinsip seleksi yang akan dilakukan, falsafah seleksi serta alat bantu seleksi yang dipakai. Sedangkan untuk pengadaan bahan pustaka khususnya yang berkaitan dengan proses pembelian yaitu dari mulai proses pemesanan bahan pustaka, penerimaan sampai dengan tahap administrasi pengadaan bahan pustaka.

dan $\begin{gathered}\text { Berdasarkan hasil observasi } \\ \text { wawancara dengan para }\end{gathered}$ pustakawan yang bertugas di bagian pengembangan koleksi DISPUSIPDA Provinsi Jawa Barat terungkap bahwa dalam melakukan penyeleksian bahan pustaka didasarkan pada hasil analisis kebutuhan dan kebijakan seleksi yang telah dibuat. Dalam penyeleksian bahan pustaka yang akan dipilih ada beberapa prinsip yang digunakan sebagai SOP diantaranya kemutakhiran, relevansi, pengarang, penerbit, dll. Untuk alat bantu seleksi yang dipakai dari hasil pengamatan dan wawancara diketahui bahwa pustakawan masih memanfaatkan daftar katalog penerbit sebagai alat bantu untuk memilih buku-buku yang akan dibeli. Dalam konteks perkembangan teknologi informasi, nampaknya para pustakawan DISPUSIPDA Provinsi Jawa Barat belum banyak memanfaatkan teknologi informasi, padahal sebagaimana diketahui banyak informasi tentang bahan pustaka yang bisa diakses secara on-line misalnya Palasari.Com, Amazon.com, Gramedia.com serta beberapa situs lainnya yang dapat memberikan informasi tentang bahan-bahan pustaka. Dengan memanfaatkan teknologi informasi ini sebenarnya proses penyeleksian bahan pustaka dapat dilakukan lebih cepat dan koleksi-koleksi yang akan dipilih bisa lebih lengkap dan beragam lagi, karena informasi dari situs ini lebih lengkap dan mencakup beberapa penerbit berbeda dengan penggunaan daftar katalog penerbit hanya memberikan informasi buku-buku yang diterbitkan oleh satu penerbit.

Kemudian untuk proses pengadaan bahan pustaka yang dilakukan di DISPUSIPDA Provinsi Jawa Barat dimulai dari proses pemesanan buku pada penerbit atau suplier/vendor, proses pembelian, pengecekan dan administrasi bahan pustaka. Adapun berkaitan dengan kegiatan pengadaan bahan pustaka ini dari hasil observasi dan pengamatan diketahui bahwa pengadaan masih dilakukan secara konvensional. Menurut penuturan pustakawan salah dengan menggunakan sistem yang konvensional ini proses pemesanan berjalan lambat serta jika tidak terjadi kesesuaian atau stock buku tidak ada/ habis di penerbit pemberitahuannya akan lama sampai pada pihak pustakawan, sehingga proses penggantian dengan buku yang lainnya akan terganggu. Namun demikian untuk proses pengetikan dan administrasinya di bagian pengembangan koleksi sudah menggunakan komputer hanya untuk proses penyeleksian dan pemesanan belum dilakukan secara on-line.

Diterapkannya teknologi informasi di perpustakaan menurut para pustakawan Bagian Pengembangan Koleksi DISPUSIPDA Provinsi Jawa Barat, sangat membantu mereka dalam menyelesaikan pekerjaan, namun karena keterbatasan pengetahuan dan keterampilan sebagian pustakawan serta ada beberapa ketentuan yang 
terkait dengan proses pengembangan koleksi jika dilakukan secara on-line, penggunaan teknologi digital belum bisa diterapkan khususnya di bagian pengembangan koleksi. Adapun harapan pustakawan bagian pengembangan koleksi DISPUSIPDA Provinsi Jawa Barat kedepannya penerapan teknologi informasi untuk kegiatan pemilihan dan pengadaaan bahan pustaka sudah bisa diterapkan secara penuh, sehingga pada gilirannya dapat meningkatkan efisensi kerja para pustakawannya.

\subsubsection{Pengalaman Pustakawan Di Bagian Pengolahan Bahan Pustaka Di Perpustakaan DISPUSIPDA Provinsi Jawa Barat.}

Kegiatan pengolahan adalah suatau kegiatan yang dilakuka $n$ pustakawan ketika bahan pustaka masuk ke perpustakaan dari hasil proses pemilihan pengadaan. Ada beberapa tahapan dalam kegiatan pengolahan ini yakni inventarisasi bahan pustaka, klasifikasi serta katalogisasi bahan pustaka. Berdasarkan hasil penelitian dapat dikemukakan hasil sebagai berikut.

\section{a. Pengalaman pustakawan melakukan kegiatan inventarisasi}

Pustakawan yang bertugas di bagian inventarisasi bahan pustaka DISPUSIPDA Provinsi Jawa Barat berjumlah 2 orang pustakawan dengan latar belakang pendidikan adalah SMA. Ada beberapa kegiatan yang rutin dilakukan dibagian inventarisasi ini yakni (1) melakukan pengecekan buku dari penerbit. Buku yang datang ke perpustakaan DISPUSIPDA Provinsi Jabar akan di cek jumlahnya, judulnya, penertbit serta pengarangnya. Ini bertujuan mengecek kesesuaian antara antara buku yang dipesan dengan buku yang sudah datang; (2) pengecapan dialkukan untuk memberikan indentitas kepemilikan bahan pustaka, (3) penulisan di buku Induk yakni penulisan buku dalam induk.

Berdasarkan hasil observasi
dan wawancara yang dilakukan
dengan para pustakawan yang
bertugas di bagian inventarisasi,

terungkap bahwa proses inventarisasi masih dilakukan secara manual khususnya dalam pemasukan data dalam buku induk. Hal ini terlihat dari induk yang ada dibagian inventarisasi DISPUSIPDA Provinsi Jawa Barat yang masih manual.

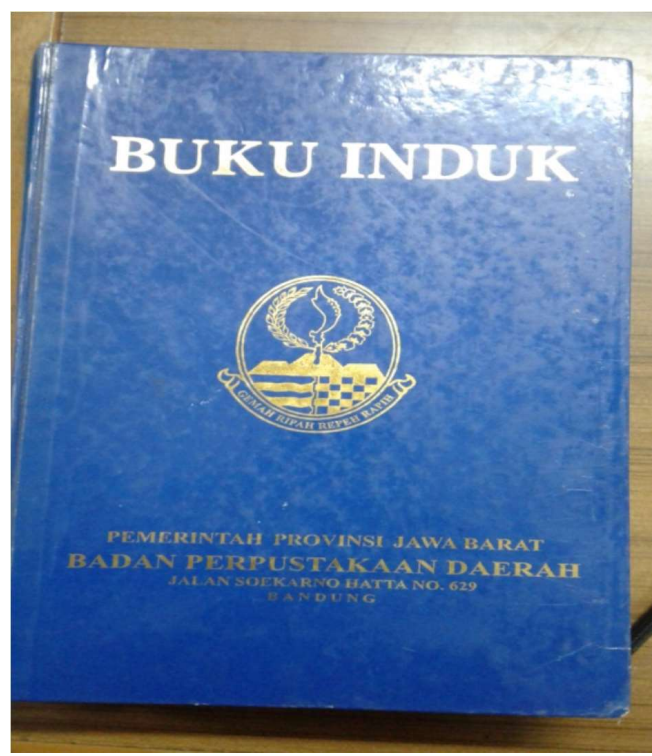

Gambar 1 . Buku Induk

Mengenai proses inventarisasi bahan pustaka menurut pengelaman pustakawan yang bertugas di bagian pengolahan masih dilakukan secara manual, bahkan untuk pencatatan dalam buku induk masih ditulis tangan. Berdasarkan pengalaman mereka dalam melakukan inventarisasi buku dalam setiap harinya paling bayak 100 buku. Belum dimanfaatnya teknologi dalam kegiatan pengolahan bahan pustaka di bagian inventarisasi akan menghambat dalam proses pengolahan selanjutnya. Oleh karena demikian pihak pustakawan mengharapkan adanya fasilitas komputer yang dilengkapi sofware yang terintegrasi, sehingga untuk proses inventarisasi seperti pengecekatan dapat dilihat dari proses pemesanan dan daftar buku yang masuk yang ada dalam sistem atau sofware pengolahan bahan pustaka. Dengan adanya sistem pengolahan yang terintegrasi bahkan online akan membantu dalam mempercepat pengerjakaan di bagian invetarsasi, sehingga in-efisiensi kerja bisa dikurangi. 
Masih berkaiatan dengan perlunya teknologi dalam kegiatan invetarisasi, menurut pustakawan DISPUSIPDA Provinsi Jawa Barat dengan adanya fasilitas komputer tentunya hanya dengan memasukan kata kunci baik itu judul ataupun nomor induknya akan sangat mudah di ketahui serta tepat, tidak seperti sekarang ini jika ingin melakukan pengecekan ulang harus membuka lembaran-lembaran pada buku induk yang pastinya akan memakan waktu dan kemungkinan besar terjadi kesalahan pada saat melakukan pengecekan.

\section{b. Pengalaman Pustakawan Dalam Kegiatan Klasifikasi Di Perpustakaan DISPUSIPDA Provinsi Jawa Barat}

Untuk menjelaskan pengalaman pustakawan dalam kegiatan klasifikasi ini perlu penulis kemukakan bahwa di Perpustakaan DISPUSIPDA Jabar yang mengerjakan bagian ini adalah merupakan pustakawan madya yang berjumlah 2 orang dengan latar belakang pendidikannya adalah S1 ilmu perpustakaan. Dengan ilmu yang mereka miliki tentu saja kegiatan mengklasifikasi bahan pepustakaan bisa di tangani dengan tepat.

Berdasarkan hasil pengumpulan data yang dilakukan oleh peneliti di lapangan, diketahui proses dari kegiatan Klasifikasi di perpustakaan DISPUSIPDA Jabar yang dilakukan oleh pustakawan bagian klasifikasi meliputi beberapa tahan sebagai berikut :

- Analisa subyek, kegiatan ini dilakukan untuk menentukan subyek suatu bahan pustaka yang sedang diklasifikasi secara tepat. Cara ini biasanya dilakukan dengan melihat judulnya, bisa juga melalui kata pengantar, atau juga melalui daftar isi dan juga melalui ringkasan yang ada pada buku tersebut.

- Pembentukan nomor klasifikasi. Dalam membetuk nomor klasifikasi, menggunakan sistem DDC (Dewey Decimal Classification) edisi 23, dan juga Tajuk Subjek yang dikeluarkan oleh Perpustakaan Nasional, serta menggunakan Perluasan Notasi $D D C$ untuk wilayah Indonesia.

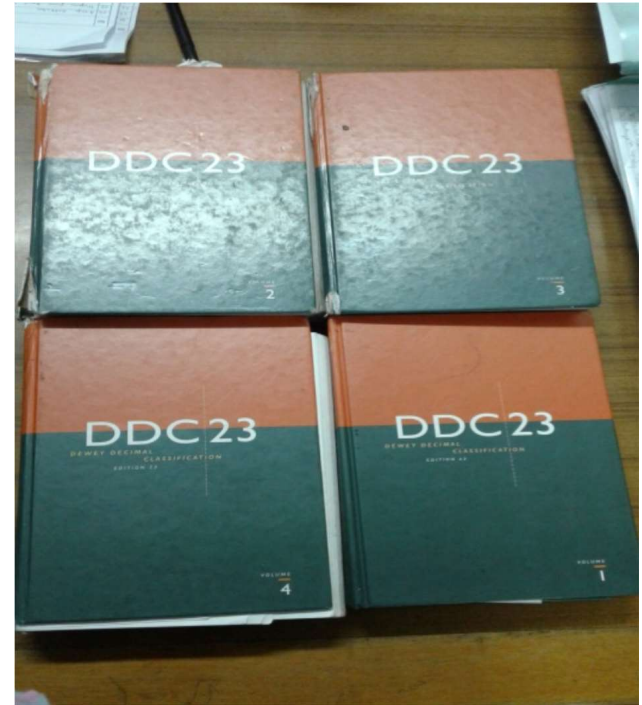

Gambar 2 . Buku Klasifikasi DDC Edisi 23

$\begin{array}{ccr}\text { Kegiatan } & \text { mengklasifikasi harus } \\ \text { dilakukan oleh orang yang memiliki }\end{array}$ pengetahuan dan keterampilan di bidang klasifikasi. Pekerjaaan ini menuntut ketelitian dalam menganalisis dan menentukan subyek suatu bahan pustaka. Adapun berdasarkan pengalaman pustakawan DISPUSIPDA Provinsi Jawa Barat yang bertugas di bagian klasifikasi ini dalam sehari untuk 2 orang tenaga pustakawan hanya mampu mengklasifikasi sebanyak kurang lebih 25 judul buku. Dalam proses klasifikasi tidak luput dari hambatan yang di alami oleh pustakawan, menurut pengalaman Ibu Sumarni pustakawan bagian klasifikasi menyatakan hambatan yang kerap dialami adalah pada saat menganalisa buku, hal ini cukup sering terjadi karena kesulitan dalam menentukan nomor klasifikasinya.

\section{Masih kurangnya jumlah buku/bahan pustaka yang bisa dibentuk nomor klasifikasinya dalam setiap yakni hanya sekitar 25 buku, memerlukan adanya terobosan untuk memanfaatkan teknologi informasi, diantaranya dengan menggunakan DDC elektronik serta perlu menyiapkan dan melakukan pelatihan klasifikasi bagi tenaga pustakawan muda yang akan ditugasi di bagian klasifikasi. Melalui pelatihan klasifikasi bahan pustaka, diharapkan dapat menghasilkan tenaga pustakawan yang terampil dalam melakukan klasifikasi bahan pustaka serta mampu menggunakan teknologi informasi khusunya DDC Elektronik.}

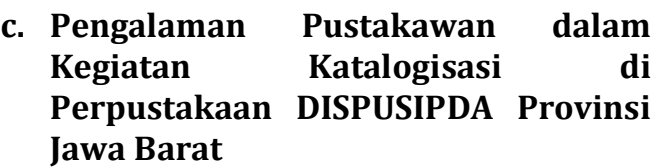


Untuk menjelaskan pustakawan dalam kegiatan katalogisasi ini perlu penulis kemukakan bahwa di Perpustakaan DISPUSIPDA Jabar yang mengerjakan bagian ini berjumlah 5 orang. untuk informan pada bagian katalogisasi kali ini adalah salah satu pustakawan madya yang berlatar belakang pendidikan ilmu hukum, namun mengikuti diklat pustakawan bagian katalogisasi selama 6 bulan di tambah lagi dengan pelatihanpelatihan yang berkaitan dengan katalogisasi dan telah memiliki sertifikat sebagai pustakawan.

Berdasarkan

hasil pengumpulan data yang dilakukan oleh peneliti di lapangan, diketahui proses dari kegiatan katalogisasi di perpustakaan DISPUSIPDA Jabar yang dilakukan oleh pustakawan bagian klasifikasi adalah sebagai berikut :

- Penulisan / penyesuaian pada Worksheet

Worksheet yang sudah selesai pada tahap klasifikasi kemudian di sesuaikan lagi di bagian katalogisasi yang selanjutnya akan di entri ke dalam sistem.

\section{- Entri data}

Entri data yang ada pada lembar Worksheet menggunakan sistem INDOMAARC dengan software yang dipakai adalah LMS (Library Managemen System) pada sebuah komputer. Data yang di entri antara lain : ISBN, Sumber Pengkatalogan, Kode Bahasa, Nomor DDC, Entri Utama- nama pengarang, Judul, penerbit, deskripsi fisik, catatan bibliografi.

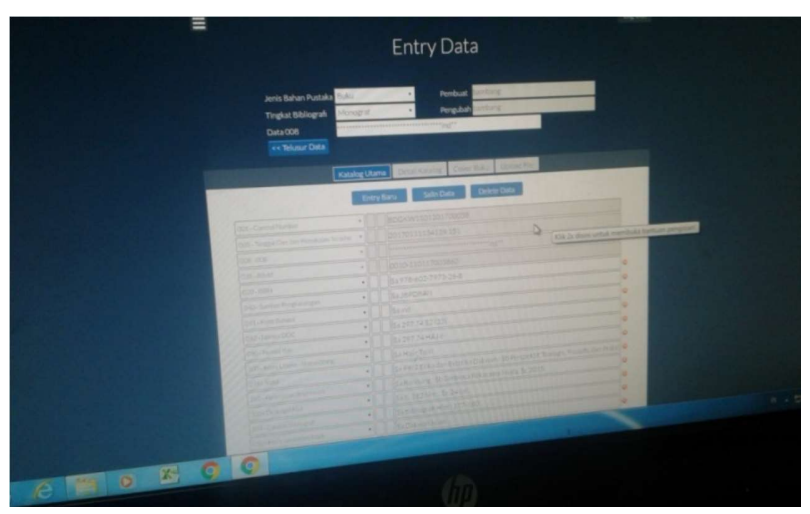

\section{Gambar 3. Entri Data Menggunakan LMS (Library Managemen System)}

Dalam proses kegiatan katalogisasi di perpustakaan DISPUSIPDA Jabar hasil yang diperoleh dalam satu hari kurang lebih dapat terselesaikan sebanyak 30 judul oleh satu orang. karena di bagian katalogisasi di kerjakan oleh 5 orang, hasil juga tergantung dari kinerja pustakawannya. Dengan 5 orang pustakawan bagian katalogisasi yang mengerjakan katalogisasi ini penanganannya sudah cukup baik sebab yang menanganinya merupakan tenaga ahli yang memiliki ilmu di bagian katalogisasi, namun ketepatan dan kecepatan serta kinerja masing-masing pustakawannya berbeda, sehingga hasil yang di perolehpun tidak menentu. Khusus untuk ibu Umi biasanya beliau dalam sehari menghasilkan 30 judul buku yang berhasil melewati tahap katalogisasi. Deangan telah diterapkannya teknologi informasi dalam kegiatan katalogisasi bahan pustaka menurut pengalaman pustakawan di bagian katalogisasi DISPUSIPDA Provinsi Jawa Barat yakni dengan adanya sofware LMS (Library Managemen System) dapat mempercepat kerja pustakawan dalam melakukan katalogisasi.

\subsection{Pembahasan}

Berdasarkan hasil pemaparan tentang pengalaman pustakawan yang bertugas di bagian layanan teknis DISPUSIPDA Provinsi Jawa Barat yang meliputi bidang penyeleksian dan pengadaan bahan pustaka, bidang pengolahan yang meliputi inventarisasi bahan pustaka, klasifikasi dan katalogisasi. Adapun hasil observasi peneliti serta pengalaman pustakawan sebagaimana yang telah dikemukakan di atas, jika dikaitkan dengan perkembangan teknologi informasi yang berjalan saat ini, nampaknya hampir sebagian besar kegiatan layanan teknis yang dilakukan di DISPUSIPDA Provinsi Jawa Barat belum menerapkan teknologi informasi, apalagi sampai harapan memasuki era library 3.0.

Rendahnya penggunaan teknologi informasi dalam pengerjaan tugas-tugas di perpustakaan DISPUSIPDA Provinsi Jawa Barat, nampak dirasakan para pustakawannya dalam melakukan pekerjaan-pekerjaan teknis dan ini 
berimplikasi pada faktor in-efisien waktu, tenaga dan biaya yang seharusnya bisa dimanaje sedemikian rupa. Berkaitan dengan hal ini nampak terlihat pada proses penyeleksian, pemesanan bahan pustaka yang sebenarnya dapat dilakukan dengan menggunakan teknologi informasi bahkan secara online akan dapat membantu mempercepat proses pekerjaaan pustakawan. Dengan menggunakan teknologi informasi proses inventarisasi dapat dilakukan dengan mengecek data pemesanan buku, data buku yang datang dalam sebuah sistem yang sama.

Kemudian untuk proses pengklasifikasi dan pengkatalogan bahan pustaka, nampaknya masih dilakukan secara manual. Adanya keterbatasan pengetahuan dan keterampilan pustakawan serta kurangnya fasilitas teknologi pengolahan dan satu-satunya software yang digunakan adalah LMS (Library Managemen System) tidak bisa diterapkan secara integratif sehingga belum mampu menjawab harapan dari para pustakawan untuk mampu bekerja cepat, tepat dan efisien. Oleh karena demikian DISPUSIPDA Provinsi Jawa Barat perlu melakukan beberapa terobosan, khususnya yang berkaitan dengan penerapan teknologi informasi dalam mendukung kegiatan penyelenggaraan perpustakaan.

\section{Simpulan dan Saran \\ 4.1 Kesimpulan}

Berdasarkan hasil penelitian sebagaimana yang telah dipaparkan di atas, maka dapat dikemukakan keseimpulan sebagai berikut :

a. Pengalaman pustakawan di bagian pengembangan koleksi pada DISPUSIPDA Provinsi Jawa, dalam melakukan kegiatan penye-leksian bahan pustaka telah mengikuti prosedur sebagaimana yang dilakukan seperti melakukan analisis kebutuhan pengguna, pembuatan kebijakan seleksi serta melakukan seleksi. Adapun untuk kegiatan seleksi bahan pustaka masih dilakukan secara manual yakni dengan melihat daftar katalog penerbit yang ada di perpustakaan. Mengenai penggunaan teknologi informasi atau yang berbasis internet di DISPUSIPDA Provinsi Jawa Barat masih belum digunakan. Untuk pengadaan bahan pustaka mulai dari pemesanan bahan pustaka masih dilakukan secara manual.

b. Untuk kegiatan pengolahan yang meliputi kegiatan inventarisasi bahan pustaka di DISPUSIPDA Provinsi Jawa Barat masih dilakukan secara manual yakni dengan memasukan daftar buku yang dibeli dalam buku induk, kemudian diberikan cap identitas perpustakaan. Belum digunakan teknologi informasi melakukan kegiatan invetarisasi bahan pustaka akan menyulitkan untuk melakukan pengecekan kesesuaian buku yang dibeli dan diterima secara cepat. Untuk kegiatan pengklasifikasi bahan pustaka yang dilakukan selama ini oleh pustakawan masih dilakukan secara manual dengan menggunakan buku DDC dan tajuk subjek. Sedangkan untuk kegiatan pengkatalogan bahan pustaka sudah mulai menggunakan sofware pengolahan data perpustakaan yakni LMS (Library Management System) namun dalam pengunaannya masih belum terintegrasi, sehingga kehadiran teknologi tidak banyak membantu kegiatan di bagian layanan teknis lainnya.

\subsection{Saran}

Berdasarkan hasil penelitian serta beberapa temuan di lapangan, maka ada beberapa saran untuk pihak terkait yakni:

a. Dalam kegiatan inventarisasi ini sebaiknya dibuatkan SOP (Standart Operational Procedur) tujuannya adalah untuk mengatur setiap pekerjaan yang harus di lakukan pada bagian inventaris ini dengan begitu jika ada penggantian staf tidak perlu selalu diberikan pengarahan lagi karena sudah ada SOPnya.

b. Dalam mendukung tugas-tugas di bagian layanan teknis supaya dapat bekerja secara efektif dan efisien. Ada baiknya pihak DISPUSIPDA Provinsi Jawa Barat memilikirkan untuk bisa menerapkan teknologi informasi yang lebih bersifat integratif mulai kegiatan penyeleksian sampai pada pelayanan pada pengguna dalam sebuah sistem. Hal ini mengingat jika menggunakan teknologi informasi banyak pekerjaaan 
yang seharusnya dapat dilakukan satu kali, maka jika dilakukan secara manual dapat dilakukan secara berulang-ulang.

c. Untuk tetap mengikuti perkembangan ilmu pengetahuan dan teknologi, ada baiknya pihak DISPUSIPDA Provinsi Jawa Barat mengadakan pelatihan tentang teknologi informasi maupun secara bergiliran mengirimkan karyawannya untuk mengikuti berbagai kegiatan ilmiah yang diselenggarakan lembaga perpustakaan, dokumentasi mapun perguruan tinggi, sehingga para pustakawannya awarre terhadap berbagai perkembangan ilmu pengetahuan dan teknologi yang terjadi saat ini.

\section{Daftar Pustaka}

Basuki, Sulistyo. 1991. Pengantar Ilmu Perpustakaan. Jakarta : Gramedia Pustaka Utama.

Bungin, Burhan. 2006.

Analisis Data Penelitian Kualitatif. Jakarta; Radja Grafindo Perkasa.

Hilmayah. 2013. "Layanan dan Pelayanan Perpustakaan: Menjawab Tantangan Era Teknologi Informasi".

Kao, Mary L. 2001. Introduction To Tecnician Services for Library Technician, Library Unlimited, London.

Kuswarno, Engkus. 2009. Fenomenologi : Konsepsi, pedoman dan contoh penelitian, Bandung : Widya Padjadjaran.

Lasa. 2007. Manajemen Perpustakaan Sekolah. Yogyakarta: Pinus

Moleong, Lexy J. 1989. Metode Penelitian Kualitatif. Bandung : Remadja Rosda Karya.

Nasution, S. 1988. Metode Penelitian Naturalistik Kualitatif. Bandung : Tarsito.

Noerhayati. 1987. "Pengelolaan Perpustakaan". Bandung: Alumni
Soeatminah. (1992). "Perpustakaan, Kepustakawanan dan Pustakawan." Yogyakarta: Kanisius.

Supriyanto, Wahyu. 2008. Teknologi Informasi Perpustakaan. Yogyakarta: Penerbit Kanisus.

Sutarno NS. 2006. Perpustakaan dan Masyarakat. Jakarta: Sagung Seto

Winoto, Yunus. 2017. Makna Diri Alpha Female Pada Pustakawan Perempuan : membangun citra positif perpustakaan melalui kiprah pustakawan perempuan sebagai alpha female, Jurnal Humanus, UNP 2017.

\section{Sumber Lain :}

www.bapusipda.jabarprov.go.id (di akses pada 2 juni 2016)

www.repository.usu.edu (di akses pada 12 januari 2017) 